\title{
Colonial Conflicts leads to Alienation and Rootlessness in Achebe's No Longer at Ease
}

\author{
Dr. Sakshi \\ (Assistant Professor, Dept. of Humanities, NIT Uttarakhand, India)
}

\begin{abstract}
This article is an effort to bring in light the theme of alienation and rootlessness generated by colonial conflicts in Achebe's No Longer at Ease. Achebe through his writing shows that how colonial rule and English education reject native values and try to install Christianity as the only true faith and consider themselves racially superior to the natives. The whites colonize the natives to dominate over them and impost their own ideas and religious beliefs on them. Colonizer induced the colonized natives to abandon the way of life and culture and imitate the colonial's. As a result native began to practice European thinking and started to alienate from their culture and society For Achebe the worst consequences of colonization is that one is currently alienated from his own community. It seems that Achebe has conceived the story in the light of his own experience during the colonization of Africa by the whites. The purpose of this paper is to show how colonial conflicts bring changes in the life of natives and how they began to alienate from their own roots.
\end{abstract}

Keywords - Achebe, Alienation, Colonial Conflicts, Community and Education.

A man's alienation means his dehumanization, his estrangement from his own community, society and eventually from his own self. In the words of Sidney Finkelstein alienation is "a psychological felt toward something seemingly outside oneself which is linked to oneself, a barrier erected which is actually no defense but an impoverishment of oneself'. (Joseph, 106-7) ${ }^{[1]}$

The protagonist as an alienated human being or outsider is a re-current character in post-colonial writing. The protagonist in such writing began to alienate from his culture, community and society due to some alien forces and western-education. The depiction of alienation and rootless ness forms a continuing thematic concern not only to Achebe but also to the writers like Richard Wright, Ralph Ellison, Ishmall Roid, Ngugi Anita Desai, Arun Joshi Nyantara Sahgal, V.S Naipal etc.

Frantz Fanon in "Black Skin, White Marks" locates alienation within the colonial situations, and maintains that the colonized is alienated not only from his colour and the traditional community, but from his very being as a black person because the Black man has no ontological resistance in the eyes of the Whiteman.

Thus such people become strangers in their own nation and are called black white men. After getting western education and Western thinking there began a transformation of the native in to something other himself-a westernized native. Native people began to adopt western practices and culture. They forget their own identify. They started mimicry of the white men and their culture. This alien civilization and their education bring a sense of alienation in Nigerian youth. Achebe describes the pathetic situation faced by those born at the crossroads of culture and therefore unable to allegiance neither to their own native values nor to the values inherited by them by being exposed to the Western materialism.

The protagonist, Obi Okonkwo, grandson of Okonkwo, the tragic hero of Things Fall Apart is also a product of alienation from his own community, society and culture. It was due to his western education and new ideas and way of life developed by his education. He tries to negotiate between his communal living and new way of thinking but never succeeds. In the words of his friend Joseph, "his mission house upbringing and European education had made him stranger in his country." "2] (Achebe, 77). His father is the rebellious son of Okonkwo who left home for Christian Church and was educated in mission school. The novel begins after things have fallen apart; Nigeria is between societies. Obi no longer belongs to the old society. He receives a similar education and is selected by Igbo community to study in England. After getting western education he considers himself an independent youth, with a Western concept of government and administration. The title taken from Yeats poem "The journey to Magi" itself explains the psychic dislocation experience by the protagonist and the general confusion that has spread in Africa as well. Obi is "no longer at ease, in the old dispensation". The story is about the practical difficulties of Obi as an ordinary individual separating himself cleanly from the past while adapting to the glitter and temptations of the new. Achebe comments on the character of Obi,

"His abortive effort at education and culture, though leaving him totally unredeemed and unregenerated, had nonetheless done something to him-it had deprived him of his links with his own people whom he no longer understood and who certainly wanted none of his dissatisfaction or pretension. (Ghosh, 45) ${ }^{[3]}$ 
The novel directly deals with distress and difficulty of Nigerian youth amidst contemporary social, economic and political problems of Africa. In the words of Innes,

No longer at Ease is the story of a young man who, educated by the British, attracted by much of what British civilization has to offer, employed by the British, seeks to live up to a new inflated image created by his position, falls into debt, takes bribes, is caught, tried and convicted. (Achebe, 42$)^{[4]}$

The novel begins at the end of Obi's career with his trial in the High Court of Lagos and with the question of Judge: how a young man with his education and brilliant promise could have done this and the rest of the novel, a long retrospect of Obi's career seeks to answer this question. Achebe gives us two opposite views on Obi's action one of European's and other of members of Umuofia Progressive Union. Mr. Green Obi's boss, explains his disgrace and announces in his club, "the Africa is corrupt through and through' because for centuries Africa 'has been the victim of the worst climate in the world and of every imaginable disease. Hardly his fault. But he has been sapped mentally and physically.'(Achebe, 3$)^{[5]}$ For Green and the other members of the British club, Obi and all Africans belong to a race apart, whose psychology and mentality is permanently alien. Then we are switched to the view of Obi's fellow villagers, for whom Obi is permanently a kinsman, a brother against whom anger 'was felt in flesh, not in the bone'. (Achebe, 4$)^{[6]}$ The members of U.P.U of Lagos branch are not interested in African corruption but are more concerned with the downfall of Obi, to whom they sent to England for higher studies. They too are baffled by Obi's action but in their case it is his naivety that troubles them. Obi is not blamed for accepting the bribe, but criticized for having stooped for the petty amount involved as the president says, "it was a thing of shame for a man in the senior service to go to prison for twenty pounds. He repeated twenty pounds, spitting it out. (Achebe, 5) ${ }^{[7]}$ All of them pity Obi's naivety and indiscretion in doing, what everyone does without finding out how it was done and they think "He should not have accepted the money himself. What others do is tell you to go and hand it to their houseboy." (Achebe, 5) ${ }^{[8]}$ David Carroll describes the differences of these two cultures of which obi is the hybrid product in these words,

To the Europeans it is inconceivable that someone who has had the privilege of a Western education should not adhere to the rules of conduct it enshrines. To the Africans of Umuofia it is disturbing that their most learned offspring, who has been educated for the glory of the clan and to look after their interests, should be so incompetent in the elementary conventions of bribe taking. ( Carroll, 63 $)^{[9]}$

After it the novel takes a form of a long flash back. And we as readers are introduce with the time of Obi's departure from his village to the University in England. Obi is sent to England by Umuofians because they not only want the education brought by the missionaries, but also a degree from English University which can provide Obi a European post. Obi leaves the village as a hero and the Reverend Osamuel Ikedi says that the departure of Obi is the fulfillment of the prophecy:

The people which sat in darkness saw a great light, and to them which sat in the region and shadow of death to them did light spring up.

These men were great in their day. Titles are no longer great, neither are barns of large number of wives and children. (Achebe, 7) ${ }^{[10]}$

Today greatness has changed its tune. Greatness is now in the things of white man. Now Umuofia sent their son to bring knowledge,

'In times past, Umuofia would have required of you to fight in her wars and bring home human heads. But those were days of darkness from which we have been delivered by the blood of the Lamb of God. Today we send you to bring knowledge. Remember that the fear of the Lord is the beginning of wisdom.'(Achebe, 9) ${ }^{[11]}$

Umuofian are happy when they arrange this educational trip for Obi. At this occasion a village elder remarks, "We too have changed our tune. We are the first in the entire nine villages to send our son to the white man's land." (Achebe, 49) ${ }^{[12]}$ U.P.U that has financed Obi's education expected him not only to repay that scholarship but return the favor in form of some activities for betterment of the community. But they don't realize that "the knowledge which brings power also brings detachment and alienation..." (Carroll, 65) ${ }^{[13]}$

The above passage clearly shows the effect of colonial powers on the traditional life of Igbo people. The things which were the symbols of greatness in traditional life have now lost their value. Obi notices right from the time he lands in Nigeria that his country is no longer the Nigeria of his dreams but it has already advanced in corrupt practices such as taking bribe. When he returns from England, in the second chapter we find the contrast perception of Obi about Lagos before and after his trip to England. First as a young member of the village community, he accepts the romantic accounts of this place, the nearest thing to Europe where 'there is no darkness... because at high the electric shines like the sun'. But on his return for him Lagos is a scenario of dead dogs, bad smell and sewage.

Here was Lagos, thought Obi; the real Lagos he hadn't imagined existed until now. During his first winter in England he had written a callow, nostalgic poem about Nigeria. It wasn't about Lagos in particular, but Lagos was part of the Nigeria he had in mind. 
'How sweet it is to beneath a tree

At even time and share the ecstasy

Of jocund birds and flimsy butterflies;

How sweet to leave our earthbound body in its mind,

And rise towards the music of the spheres,

Descending soft with wind,

And the tender glow of the fading sun.

He recalled this poem and then turned and looked at the rotting dog in the storm drain and smiled. 'I have tasted putrid flesh in the spoon,' he said through clenched teeth. 'Far more apt.' At last Clara emerged from the side street and they drove away. (Achebe, 14-15) ${ }^{[14]}$

So Obi's conception of Nigeria has changed and a sense of alienation has taken place in him. His alienation is apparent first to the members of U.P.U at the celebration function of Obi's return at Lagos. They become disturbed by Obi's appearance in shirt sleeves, even his fellow traveler came well dressed in black suit. They also become surprised by his unimpressive speech of thanks and by his strange system of value as he says that his education is for service, not for white-collar jobs and comfortable salaries. The secretary of progressive union tries to regain control on Obi and he reminds him that he has sent to England for further studies in accordance with the usual practice by his kith and kin by their hard earned money. In return they expect him to bring honour and prosperity to their village. They now expect to enjoy, 'the great honour Obi had brought to the ancient town of Umuofia which could now join the comity of other towns in their march towards political irrendentism, social equality and economic emancipation'. "The importance of having one of our sons in the vanguard of this march of progress is nothing short of axiomatic. Our people have a saying "Ours is ours, but mine is mine." (Achebe, 28) ${ }^{[15]}$

But later in novel Obi quickly feels that the demands being made upon him are unacceptable, and he is an alien with a different set of values. For him, "the demands of the two worlds seem irreconcilable, his western education has made him "beast of no nation..." ${ }^{[16]}$ (Innes, 44). At his return he is stable enough to thwart the practice of accepting bribes in his personal life. So when he travels home on his first visit to the village, he becomes surprised to see this corrupt custom in Nigeria. He expresses his disaster and he and his friend Christopher theorized about bribery in Nigerian public life and argue about Nigeria's future. For Obi the public service of Nigeria would remain corrupt until the old Africans at the top were replaced by young men from universities. He says in the colonized language, 'What an Augean stable!' he muttered to himself. 'Where does one begin? With the masses? Educate the masses?' he shook his head. 'Not a chance there. It would take centuries..... (Achebe, 40) $)^{[17]}$

Obi sees a dream to remove the corrupt practices, when he journeys home he has certain definite ideas regarding his future. He gets a more triumphant welcome at his home than Lagos. The villagers welcome him as a returning hero, without any suspicion of his cultural dislocation. The village greets him in same terms as they send him to England. The conflict is also seen in the attitude of Obi's father towards the villagers as they say that Christianity has made him blind because he is the only man to fail to see that on such happy occasion he should offer wine, a cock and little money to the chief rain-maker in Umuofia. The old man also says that kola nut must be broke in thanks to their idols as Obi has returned from the land of the spirits. But Isaac, Obi's father says that this is a Christian house and Kola nut is not sacrificed here to idols. As Carroll clears out, "The crisis of Obi's return indicates clearly that however thoroughly the Igbo and Christian ingredients are mixed they will never coalesce. On the slightest pretext they separate and regroup for open conflict." (Achebe, 73) ${ }^{[18]}$ In Obi's house we also observe this contrast of religions. From his childhood Obi experiences that his parents have always stressed on different values and culture. On the one side his father always insisted upon the Christian education but on the other side his mother tried to educate him with her native tales.

After it the story again shifts from the village scene to Lagos where Obi joins his job. This middle part of the novel moves with in each chapter from his office to varied scenes of city life. We are introduced with Mr. Green Obi's boss, who is thorough colonialist, and believes in the supremacy of the white race. But his work ethic is beyond reproach, he sees the pursuit of duty as an end in itself is quite divorced from personal interest of any kind. Obi even after his dislike towards Mr. Green admits that,

... he nevertheless had some admirable qualities. Take, for instance, his devotion to duty Rain or shine, he was in the office half an hour before the official time, and quite often worked long after two, or returned again in the evening. Obi could not understand it. Here was a man who did not believe in a country, and yet worked so hard for it. Did he simply believe in duty as a logical necessity? (Achebe, 96) ${ }^{[19]}$

Later Achebe unfolds two main events first Obi's acquisition of a car and second his girlfriend Clara's revelation that she is an Osu (an outcast). Obi knows that neither his parents nor his people will agree with the idea of marrying an Osu as they have already warned him when he was leaving his village. The first event becomes the chief cause of Obi's financial problems. He has to pay the installments of his car and also refund the money to U.PU. The U.P.U is also delighted by Obi's achievements his job and his new car. Having 
invested in his career at great sacrifice, they now look forward to the rewards, and it is Obi's duty to make these as ample as possible. As an old man says,

'That is why we say that he who has people is richer than he who has money... 'We now have one of our sons in the senior service. We are not going to ask him to bring his salary to share among us. It is in little things like this that he can help us. It is our fault if we do not approach him. Shall we kill a snake and carry it in our hand when we have a bag for putting long things in.'(Achebe, 72) ${ }^{[20]}$

On the one side Obi has assured himself that he cannot give up the car because that would be letting down to the Clan. Obi has decided to request the members of Umoufia Progressive Union for granting him some more time before he began to start returning their money. The Union agrees to Obi request, but the president takes the opportunity to give Obi some advice on how to manage his finance, and says that he should not make any relationship with an Osu girl. At this Obi storms out in a range as he thinks that he has his own right to make his own choice without interference. He has decided that he will not give up Clara, for him it was either Clara or nobody. In his view the clan has no right to interfere in his personal affairs. He refuses to be controlled by outdated tribal practices; he is an individual who must be allowed to exercise the supreme choice of his own wife. The words about Clara get back to his village and his father summoned him home. His pressures and complications grow up when he declares that he wants to marry Clara an Osu. His parents oppose the idea of Obi. His father's reaction is unexpected:

His father laughed. It was the kind of laughter one sometimes heard from a masked ancestral spirit..... And the meaning of that laughter was clear: I did not really think you would know, you miserable human worm!'(Achebe, 120) $)^{[21]}$

When Obi argues with him that they are Christians and cannot accept the Osu prohibition because in Christianity where are no bound, no free. His father replies,

'Osu is like leprosy in the minds of our people. I beg of you, my son, not to bring the mark of shame and of leprosy into you family. If you do, your children and your children's children unto the third and fourth generations will curse your memory. It is not for myself I speak; my days are few. You will bring sorrow on your head and on the heads of your children. Who will marry your daughters? Whose daughters will your sons marry? Think of that, my son. We are Christians, but we cannot marry our own daughters.'(Achebe, 121) 122] $^{[2}$

Even Obi holds his mother in high regard and is constantly aware of her sacrificing nature. Yet her vehement disapproval of his intended marriage to Clara has him in shocked dismay as his mother declares, if you want to marry this girl, you must wait until I am no more... 'but if you do the thing while I am alive, you will have my blood on your head, because I shall kill myself.'(123) Obi was shake by his mother's response and his engagement with Clara had now turned into utter despair. He was amazed at the thoughts that posed to his mind at this time of greater crises in his life; His mind was troubled not only by what had happened but also by the discovery that there was nothing in him with which to challenge it honestly. Obi feels himself in utter confusion and he thinks that he can neither accept his parents' values nor reject them. He was suffocated by the cultural orthodoxy of the elders. He feels isolated from his community and it seems that Achebe's concerns, obviously, lean towards the community rather than the individuals as S.A. Khayyoom remarks about this isolation of individuals in African Novels,

The isolation of the individual in African novel makes him typical and representative of his society.... It is the will of the majority that consciously contributes towards a coherent and organic African society. But the problem for a sensitive, self-conscious creative being is how to decline himself from his group and to assert his individuality. (Khayyoom, 26) ${ }^{[23]}$

Obi gets hurt from his parents' behavior. He retreats and shuts himself away from his family, from his community, knowing fully well that his behaviour is hurtful. So he returns to Lagos and at his return he sees problems building up when he comes to know about Clara's pregnancy. Clara also feels humiliated at the familial and social rejection that she not only breaks off the engagement but also decides to abort her child. Obi essentially abandons his responsibility towards her in his weak, halfhearted respect for his family's wishes. After her abortion Clara disappears from Obi's life and finally Obi's hears of his mother's death. Both the incidents affect the moral and emotional world of Obi. Obi's absence from the funeral is called a thing of shame. $\mathrm{He}$ in his financial crisis stop paying to U.P.U. and he also fails at his job, as he resists self-righteously various bribes until his financial situation and morals finally collapse. Unfortunately, he is as clumsy here as in his personal relations. He is arrested and sentenced to prison. So the novel ends, as it began, at the trial where Africans and Europeans alike are dismayed by this sudden debacle of Obi's career. Obi wants to clean Nigeria of its evils and his intentions are ideally good, but he fails to carry them out in his life because of the negative change in values. From such heights of heroic ideals Obi stoops to accepting bribe, himself. The society Obi functions in is one, where the processes of history have destroyed the traditional values. There is no set moral code nor are there any models for emulation and a young man like Obi is left to himself to solve his moral problems. As it is clear that Obi in his anxiety to fulfill his obligations to his family and tribe and play his role 
well in the aristocratic circles of Lagos, runs in to debts and succumbs to temptation eventually. Obi's fall symbolizes the failure of educated youth of Nigeria and raises considerable alarm about the future of the nation.

Thus the crucial problem of a pre-independent society is posed in the novel that due to western influence native youth are disinherited from their own folk culture, and exposed to the alien value. He has come with the double world, the native and the European. In the words of Abiola Irele:

Obi's dilemma is contained in the conflict between his developed intellectual insight and his lack of moral strength to sustain it... His weakness of character is reflected in his inept handling of his human relationships and of his material problems; he is an individual with no sense of order.... Obi is never really prepared to engage in any sort of sustained effort, with the result that he flounders through his life. $(\text { Cook, } 85)^{[24]}$

\section{References}

[1] Joseph, S. Johnpeter. "Alienation and Rootlessness in the Novels of Kamla Markandaya”.ed.Nandani, Sahu. The Post Colonial Space: Writing the self and the nation. (New Delhi : Atlantic Publishers and distributers, 2007.)

[2] Achebe, Chinua. No Longer at Ease. (London: Heinemann, 1960.)

[3] Ghosh, Anuradha. "The Notion of Identity Formation and the Paradigm of Cultural Resistance, in the Novels of Chinua Achebe". ed. Mala Pandurand. Chinua Achebe:Anthology of Recent Criticism. (Delhi: Pencraft Internation, 2006)

[4] Achebe, Chinua. No Longer at Ease. (London: Heinemann, 1960.)

[5] Achebe, Chinua. No Longer at Ease. (London: Heinemann, 1960.)

[6] Achebe, Chinua. No Longer at Ease. London: Heinemann, 1960.

[7] Achebe, Chinua. No Longer at Ease. (London: Heinemann, 1960.)

[8] Achebe, Chinua. No Longer at Ease. (London: Heinemann, 1960.)

[9] Carroll, David. Chinua Achebe. (Macmillan, 1980.)

[10] Achebe, Chinua. No Longer at Ease. (London: Heinemann, 1960.)

[11] Achebe, Chinua. No Longer at Ease. (London : Heinemann, 1960.)

[12] Achebe, Chinua. No Longer at Ease. (London: Heinemann, 1960.)

[13] Carroll, David. Chinua Achebe. (Macmillan, 1980.)

[14] Achebe, Chinua. No Longer at Ease. (London : Heinemann, 1960.)

[15] Achebe, Chinua. No Longer at Ease. (London: Heinemann, 1960.)

[16] Innes, C.L. Chinua Achebe. (Cambridge University Press, 1990.)

[17] Achebe, Chinua. No Longer at Ease. (London: Heinemann, 1960.)

[18] Achebe, Chinua. No Longer at Ease. (London: Heinemann, 1960.)

[19] Achebe, Chinua. No Longer at Ease. (London : Heinemann, 1960.)

[20] Achebe, Chinua. No Longer at Ease. (London: Heinemann, 1960.)

[21] Achebe, Chinua. No Longer at Ease. (London : Heinemann, 1960.)

[22] Achebe, Chinua. No Longer at Ease. (London: Heinemann, 1960.)

[23] Khayyoom, S.A. Chinua Achebe: A Study of His Novels. (New Delhi: Prestige Books, 1999.)

[24] Cook, David. African Literature. (London: Longman group limited, 1997.) 